IJBPAS, February, 2021, 10(2): 608-612

ISSN: 2277-4998

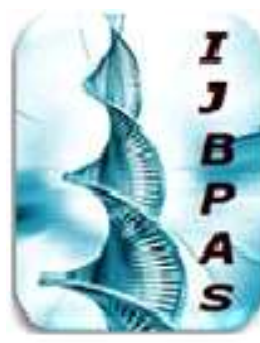

International Journal of Biology, Pharmacy

and Allied Seiences (IJBPAS)

'A Bridge Botusen Laboratory and QRender'

WwW.jibpas.com

\title{
SUDHASHATKA YOGA: A REVIEW
}

HUSSAIN $\mathbf{G}^{1^{*}}$ AND KADIBAGIL VR ${ }^{2}$

${ }^{1}$ Associate Professor, ${ }^{2}$ Professor, Department of Rasashastra \& Bhaishajya Kalpana, Sri

Dharmasthala Manjunatheshwara College of Ayurveda \& Hospital, Hassan, India

*Corresponding Author: Gazala Hussain: E Mail: gazalanabeel@gmail.com

Received $16^{\text {th }}$ April 2020; Revised $29^{\text {th }}$ May 2020; Accepted $26^{\text {th }}$ July 2020; Available online $1^{\text {st }}$ Feb. 2021

https://doi.org/10.31032/IJBPAS/2021/10.2.5373

ABSTRACT

Ayurveda Pharmaceutics deals with preparation of formulations with drugs comprising of herbs, metals, minerals, etc. The origin of the drugs could be herbs, mineral, marine or animal products. These drugs will be in crude form and hence before application in formulations, they are subjecting to various processes. The formulations are a combination of these dravyas alone or in combination viz., herbal, herbo-mineral, herbo-marine, marine-animal products, etc. One such formulation is Sudhashatka yoga where it is a combination of six ingredients namely Pravala, Shukti, Shankha, Kaparda, kurmaprishta and godanti. It is a formulation comprising of mineral drug, marine drug and animal origin drug. As these drugs are a composition of calcium, this compound formulation is indicated in calcium deficiency in children.

Keywords: Calcium, shankha, pravala, shukti, shankha, ayurveda pharmaceutics INTRODUCTION

Formulations in Ayurveda pharmaceutics are a combination of herbopravala, shukti, shankha, kaparda, godanti mineral drugs, mineral-metallic compounds, and kurmaprishta which is an animal product. etc. The combination of ingredients also is All the ingredients taken are in the form of varied; it could be of animal origin drugs, bhasma (calcified ash). The marine dravyas mineral origin, metal origin, etc. One such formulation is sudhashataka yoga that is a are subjected to shodhana (purification), marana (incineration) by processing with 
herbal juices or decoctions and subjecting to specified amount of graded heat by which it turns into the form of ash. The bhasma of all the ingredients are mixed homogenously and used as indicated with specified adjuvant (Table 1, 2).

Method of preparation: All the bhasma are taken in a khalva yantra and bhavana (trituration) is given with nimbu rasa (Citrus limon) for three times and pills of a ratti size are prepared.

Dose: $2-8$ ratti (250mg to $1 \mathrm{~g}$ ) with milk as adjuvant.

Indications: In deficiency of calcium, bala shosha (emaciation).

Table 1: Ingredients of the formulation [1]

\begin{tabular}{|c|c|c|}
\hline Sl. No. & Ingredients & Proportion \\
\hline 1 & Pravala bhasma (calyx of coral) & 1 part \\
\hline 2 & Shukti bhasma (calyx of oyster shell) & 2 parts \\
\hline 3 & Shankha bhasma (calyx of conch shell) & 3 parts \\
\hline 4 & Kaparda bhasma (calyx of cowries) & 4 parts \\
\hline 5 & Kurmaprishta bhasma (calyx of back of tortoise) & 5 parts \\
\hline 6 & Godanti bhasma (calyx of gypsum) & 6 parts \\
\hline
\end{tabular}

Table 2: Properties of the ingredients

\begin{tabular}{|c|c|c|c|c|c|c|}
\hline S. No. & Rasa dravya & Rasa & Guna & Veerya & Doshaprabhava & Karma \\
\hline 1 & $\begin{array}{l}\text { Pravala } \\
\text { (calyx of } \\
\text { Coral) }\end{array}$ & $\begin{array}{l}\text { Kashaya } \\
\text { (astringent), } \\
\text { Madhura } \\
\text { (sweet), } \\
\text { Amla (sour) }\end{array}$ & $\begin{array}{l}\text { Laghu, snigdha } \\
\text { (unctuous), } \\
\text { sheeta (cold) }\end{array}$ & $\begin{array}{l}\text { Sheeta } \\
\text { (Cold) }\end{array}$ & $\begin{array}{c}\text { Pittajit, } \\
\text { Tridoshaghna } \\
\text { (alleviates all the } \\
\text { doshas) }\end{array}$ & $\begin{array}{l}\text { Vrishya (aphrodisiac), Balya } \\
\text { (strengthens body), } \\
\text { Grahadoshahara (Psychosis), } \\
\text { Chakshushya (beneficial for } \\
\text { eyes), useful in vishajara roga } \\
\text { (toxic symptoms) }\end{array}$ \\
\hline 2 & $\begin{array}{c}\text { Shukti } \\
\text { bhasma } \\
\text { (calyx of } \\
\text { oyster shell) }\end{array}$ & $\begin{array}{l}\text { Madhura } \\
\text { (sweet) }\end{array}$ & $\begin{array}{l}\text { Susheeta } \\
\text { (cold), Laghu } \\
\text { (light) }\end{array}$ & $\begin{array}{l}\text { Sheeta(C } \\
\text { old) }\end{array}$ & $\begin{array}{l}\text { Kaphapittahara( } \\
\text { alleviates kapha } \\
\& \text { pitta dosha) }\end{array}$ & $\begin{array}{l}\text { Brimhana (nourishing), vrishya } \\
\text { (aphrodisiac), ayushya } \\
\text { (increases longevity), } \\
\text { asthidantavivardhana } \\
\text { (strengthens bones \& teeth), } \\
\text { pushtikara (nourishing), } \\
\text { deepana (appetiser), bedana, } \\
\text { kantiprada (increases } \\
\text { complexion), balya } \\
\text { (strengthening), chakshushya } \\
\text { (increases vision), veeryaprada }\end{array}$ \\
\hline 3 & $\begin{array}{c}\text { Shankha } \\
\text { bhasma } \\
\text { (calyx of } \\
\text { conch shell) } \\
\end{array}$ & $\begin{array}{l}\text { Kshariya } \\
\text { (alkaline) }\end{array}$ & & $\begin{array}{l}\text { Sheeta(C } \\
\text { old })\end{array}$ & & $\begin{array}{l}\text { Balavardhaka (increases } \\
\text { strength), grahi (binding) }\end{array}$ \\
\hline 4 & $\begin{array}{c}\text { Kaparda } \\
\text { bhasma } \\
\text { (calyx of } \\
\text { cowries) }\end{array}$ & $\begin{array}{c}\text { Katu } \\
\text { (pungent), } \\
\text { Tikta (bitter) }\end{array}$ & $\begin{array}{l}\text { Guru (heavy), } \\
\text { Ushna(Cold) }\end{array}$ & $\begin{array}{l}\text { Ushna } \\
\text { (Hot) }\end{array}$ & $\begin{array}{l}\text { Kaphavatahara } \\
\text { (alleviates kapha } \\
\text { \& vata dosha) }\end{array}$ & $\begin{array}{c}\text { Deepana (appetizer), Vrishya } \\
\text { (aphrodisiac), Netrya (increases } \\
\text { vision), rasayana (rejuvenative), } \\
\text { shukrakara, doshahari } \\
\text { (alleviates the disorders), }\end{array}$ \\
\hline 5 & $\begin{array}{l}\text { Godanti } \\
\text { bhasma } \\
\text { (calyx of } \\
\text { gypsum) }\end{array}$ & - & Sheeta & Sheeta & $\begin{array}{l}\text { Pittadoshahara(a } \\
\text { lleviates pitta } \\
\text { dosha) }\end{array}$ & $\begin{array}{l}\text { Balya (strengthening), deepana } \\
\text { (appetizer), jwarahara (anti- } \\
\text { pyretic), shulahara (analgesic) }\end{array}$ \\
\hline
\end{tabular}




\section{DISCUSSION}

The ingredients are all compounds of calcium and four of these are marine drugs namely, shankha, shukti, kaparda, pravala, one is a mineral drug namely Godanti and another is of animal origin i.e., kurmaprishta (calyx of back of tortoise).In a study carried out previously it is said that Calcium is present in the form of oxide $(\mathrm{CaO})$; in Shankha it is $53.964 \% \mathrm{w} / \mathrm{w}$, in Shukti $54.844 \%$ w/w, in Varatika $54.984 \%$ w/w. The comparative quantity of calcium was more in the case of Varatika bhasma and less in Shankha bhasma [2].

An analytical study on pravala highlights that the elements present in Pravalabhasma are $\mathrm{Ca}(38.69 \%), \mathrm{O}(40.66)$, $\mathrm{C}(12.70 \%), \operatorname{Mg}(4.61 \%), \mathrm{Si}(0.88), \mathrm{S}(0.45 \%)$, $\mathrm{Fe}(0.37 \%), \quad \mathrm{Na}(0.36 \%), \quad \mathrm{Al} \quad(0.36 \%)$, $\mathrm{Sr}(0.27 \%), \mathrm{P}(0.18 \%), \mathrm{Cl}(0.17 \%), \mathrm{K}(0.15 \%)$, $\mathrm{Cu}(0.05 \%), \operatorname{Ti}(0.04 \%), \mathrm{Zn}(0.03 \%), \mathrm{Cr}, \mathrm{Zr}$, $\mathrm{Ni}, \mathrm{Mn}, \mathrm{As}, \mathrm{Mo}$ are in traces. The XRF analysis of Pravala showed, calcium as the major element, magnesium, silicon, phosphorous, manganese and iron are the minor elements; aluminum, sulfur, potassium, strontium are the trace elements [3].

In an analytical study carried out on Mukta Shukti Bhasma, it is said that calcium is present in the form of both calcite and calcium oxide hydrate form [4].

A study where the analysis of shankha carried by XRD has revealed that the pattern of both raw and finished conch when simulated with standards, clearly indicated that raw conch is aragonite in nature, while after incineration this aragonite structure got rearranged to calcite form. A direct comparison of the XRD patterns of the conch samples with the simulated patterns shows that the raw conch is calcium carbonate only in the aragonite form without any calcite content. On the other hand, the three batches of the incinerated conch reveal the presence of only calcite form of calcium carbonate without any aragonite content. Calcium oxide has not been detected in both, the raw and the incinerated conch samples [5].

In an article it is mentioned by XRD analysis of kaparda bhasma that the highest peak at 2000 in two samples of kaparda bhasma, indicated the majority presence of Calcium oxide. However there is some signature of presence of Calcium carbonate and also showed the presence of Magnesium and Potassium oxide in some extent [6].

An article on analysis of shells of dead tortoise that were donated by commercial animal traders and private 
persons when they died from various causes showed presence of various elements namely calcium, phosphorous, iron, copper and zinc. Calcium was present from $52.2 \pm 10.5$ in hatchlings to $244 \pm 21 \mathrm{~g} / \mathrm{Kg}$ in adults [7].

Godantibhasma contains $42.30 \%$ Calcium $(\mathrm{Ca})$ as calcium oxide $(\mathrm{CaO})$ when analysed by gravimetric method [8].

In another study it is said that Calcium as $\mathrm{CaO} \% \mathrm{w} / \mathrm{w}$ in praval is $72.067 \%$, in shankha $63.941 \%$, in shukti $82.891 \%$, in varatika $67.484 \%$, in godanti 45.990. The comparative quantity of calcium was more in case of shukti bhasma (82.891\%) and less in godanti bhasma (45.990\%) [9].

\section{CONCLUSION}

The formulation is indicated in deficiency of calcium and all the ingredients are a rich source of calcium. Calcium is said to be present in the form of calcium oxide in different proportions in all the ingredients used in the formulation. Shankha, shukti, varatika, godanti, pravala are all easily available ingredients. The other ingredient namely kurmaprishta can be omitted from the formulation for ethical reasons to protect the fauna of the planet. The formulation can be studied as a supplement for calcium deficiency diseases.

\section{REFERENCES}

[1] Yadavji Trikamji, Siddhayoga Sangraha. $11^{\text {th }}$ edition. Baidyanath Ayurveda Bhavan Ltd; 2000, pg. 149.

[2] Vachaly Dharmesh Damodar, et al, A Comprative Pharmaceutical and analytical study of Shankha, Shukti and Varatika Bhasma. PIJAR, Volume-I, Issue I August-September 2016.

[3] Dr. Suman lata et al, Physio-chemical analysis of Praval Bhasam - Prepared by using Praval Mool as raw material. International journal of ayurvedic \& herbal medicine.2015; 5(4) July-Aug: 1955-1963.

[4] Biradar M. H. et al, Pharmaceutico Analytical study of Mukta Shukti Bhasma. JAIMS2017; Vol 2, issue 4, July-Aug.

[5] Sandeep Chavan et al, Pharmaceutical Standardization and Physicochemical Characterization of Traditional Ayurvedic Marine Drug: Incinerated Conch Shell (Shankha Bhasma); MDPI. 2018; 16(11), 450.

[6] C. S. Maladkar, PharmaceuticoAnalytical Study of Varatika Bhasma with special reference to its types according to Rasatarangini. Ayurpub 2016; I(4): 153-159 
[7] Ellen Kienzle, et al, Chemical Composition of Turtles and Tortoises, The Journal of Nutrition, Volume 136, Issue 7, 1 July 2006, Pages 2053S-2054S

https://academic.oup.com/jn/article/1 36/7/2053S/4664838

[8] Rohit Thakkar et al, Physicochemical screening of Godanti Bhasma: An effort to Pharmaceutical Standardization, Journal of Pharmacy Research. 2017; 11(7), 887-894.

[9] Divya Prakash, et al, A comparative pharmaceutical study on $\mathrm{Ca}$ (ion) substances of various Ayurvedic calcium compounds. Int. J. Res. Ayurveda Pharm. 2013; 4(4): 586588. 